\title{
In Vitro Fluoride-Release/Recharge Pattern and Antimicrobial Effects of Current Restorative Materials Used in Pediatric Dentistry
}

\author{
Çocuk Diş Hekimliğinde Kullanılan Güncel Restoratif Materyallerden Fluorid \\ Salınımı, Yeniden Yüklenmesi ve Antimikrobiyal Etkilerinin In Vitro Olarak \\ Incelenmesi
}

\author{
Belen Şirinoğlu-Çapan'1 (1), Serap Akyüz² (1), Burçin Alev³ (D), Beste Tacal-Aslan ${ }^{4}$ (D), \\ Tanju Kadir ${ }^{4}$ (D) Ayşen Yarat ${ }^{5}$ (D) \\ 'Department of Pediatric Dentistry, Faculty of Dentistry, Biruni University, Istanbul, Turkey \\ 2Department of Pediatric Dentistry, Faculty of Dentistry, Marmara University, Istanbul, Turkey \\ ${ }^{3}$ Center of Excellence on Biomaterials, Biomechanics and Bioelectronics, TUBITAM-MAM Materials Institute, , Kocaeli, Turkey \\ ${ }^{4}$ Department of Basic Medical Sciences-Microbiology, Faculty of Dentistry, Marmara University, Istanbul, Turkey \\ ${ }^{5}$ Department of Basic Medical Sciences-Biochemistry, Faculty of Dentistry, Marmara University, Istanbul, Turkey
}

ORCID ID: B.S.C. 0000-0003-1829-0379; S.A. 0000-0002-1358-0150; B.A. 0000-0001-5122-4977; B.T.A. 0000-0001-5271-7917; T.K. 0000-0002-4668-9988; A.Y. 0000-0002-8258-6118

Cite this article as: Şirinoğlu-Çapan B, Akyüz S, Alev B, Tacal-Aslan B, KadirT, Yarat A. In Vitro Fluoride-Release/Recharge Pattern and Antimicrobial Effects of Current Restorative Materials Used in Pediatric Dentistry. Experimed 2020; 10(1): 7-15.

\begin{abstract}
Objective: The aim of this in vitro study was to investigate the fluoride-releasing/recharging and antimicrobial effects of restorative materials used in pediatric dentistry.

Material and Method: High-viscosity and resin-modified glass-ionomer cement, glass carbomer, compomer, giomer and composite were tested. Dental materials' fluoride-release was measured in distilled water (DW) and artificial saliva (AS) for eight weeks using a fluoride-specific electrode. At the end of eight weeks, specimens were divided into three groups for recharging with acidulated phosphate fluoride gel and fluoride varnish. After recharge, fluoride release was measured again. Agar diffusion test was used to assess antimicrobial effects against $S$. mutans and L. acidophilus. The statistical analysis was done with Mann-Whitney $U$ and Friedman tests using SPSS-22 software.

Results: High-viscosity glass-ionomer cement showed the highest fluoride-release in both storage media, followed by glass carbomer, while giomer demonstrated the lowest. After recharge, the increase in the varnish group was significantly higher than others $(p<0.05)$. Fluoride-release in DW groups was significantly higher than in the AS groups for all materials during the test period $(p<0.05)$. None of the materials showed antimicrobial effects.

Conclusion: It was concluded that fluoride-release from glass ionomer-based materials is higher than that from resin-based materials. Fluoride-release from materials decreases in AS. Glass carbomer can be used as an alternative to glass ionomers.

Keywords: Antimicrobial effect, fluoride-release, dental materials,
\end{abstract} giomer, glass carbomer

\section{ÖZ}

Amaç: In vitro çalışmamızın amacı çocuk diş hekimliğinde kullanılan güncel restoratif materyallerin fluorid salınımını saptamak, yeniden yükleme sonrası salınımlarını değerlendirmek ve bu materyallerin antimikrobiyal etkinliğini araştırmaktır.

Gereç ve Yöntem: Çalışmamızda yüksek viskoziteli cam iyonomer siman, rezin modifiye cam iyonomer siman, cam karbomer, kompomer, giomer ve rezin kompozit kullanıldı. Fluorid salınımı distile su (DS) ve yapay tükürük (YT) içerisinde 8 hafta boyunca fluorid spesifik elektrod ile ölçüldü. 8. haftanın sonunda örnekler üç gruba ayrıldı. Birinci gruba hiçbir ajan uygulanmazken, ikinci gruba asidüle fosfat fluorid jel, üçüncü gruba ise fluorid verniği uygulandı ve yükleme sonrası salınımları incelendi. S. mutans and L. acidophilus'a karşı antimikrobiyal etkinin değerlendirilmesinde agar difüzyon testi kullanıldı. İstatistiksel analizler SPSS-22 programı kullanılarak Mann-Whitney U ve Friedman testleri ile yapıldı.

Bulgular: Her iki ortamda da en yüksek fluorid salınımını yüksek viskoziteli cam iyonomer siman yaparken, bunu cam karbomer izledi. En düşük salınım giomerde saptandı. Fluorid yüklemesi sonrası tüm materyallerin salınımı artarken; vernik gruplarındaki artış, diğer gruplardan anlamlı düzeyde yüksek bulundu $(p<0,05)$. Çalışma boyunca materyallerin DS gruplarındaki fluorid salınımı YT gruplarından anlamlı derecede yüksek bulundu $(p<0,05)$. Materyallerin hiçbiri antimikrobiyal etki oluşturmadı.

Sonuç: Cam iyonomer esaslı materyallerden fluorid salınımının daha çok olduğu; yapay tükürük içerisinde materyallerin salınımının azaldığı ve cam karbomerin fluorid salınımı açısından cam iyonomer simanlara alternatif olarak kullanılabileceği görüldü.

Anahtar Kelimeler: Antimikrobiyal etki, fluorid salınımı, dental materyaller, giomer, cam karbomer 


\section{INTRODUCTION}

A restorative material used in dental clinics should have certain properties, such as good marginal adaptation, biocompatibility, fluoride-release and high strength. Since fluoride-containing silicate cements have been shown to prevent formation of caries, interest in fluoride-releasing materials has increased (1). Among these materials, conventional glass ionomer cement (GIC) emerges at the top because of its efficacy in resisting secondary caries formation around restoration. Presently preferred restorative materials in pediatric dentistry are fluoride-releasing materials, such as conventional glass ionomer cements, resin-modified glass ionomer cements (RMGIC), compomers, glass carbomers and giomers $(2,3)$.

Giomers are hybrid restorative materials developed over the last decade, combining the properties of "glass ionomer" and "composite" materials. Pre-reacted glass ionomer fillers (PRG) was added into the resin matrix. PRG filler is made by reacting acid-reactive glass containing fluoride with polyalkenoic acid in water before being incorporated into the resin materials. The PRG fillers allow the material to fluoride-release and recharge (4).

Glass carbomers, a new type of dental material, are glass ionomer-like cements containing carbomized nanoparticles. However, they are separated from glass ionomers by nano-sized particles and fluorapatite content. These particles reduce the solubility and increase the stress resistance. They also help to induce remineralization faster $(5,6)$.

Glass ionomer cements have anticariogenic effects because of their long-term ion releasing properties. The fluoride content of cements is consumed quite quickly in a few months. However, the glass ionomer cements have a fluoride uptake capacity from the environment. Different topical fluoride application methods (e.g. fluoride varnishes and fluoride gels) and different fluoride concentrations are used for fluoride-recharge of the materials (7). The storage medium also has an effect on fluoride-release (8).

In addition to the remineralization effect of fluoride, there are also antimicrobial effects. Fluoride acts on bacterial metabolism and plaque acidity by inhibiting glycolytic enzymes and proton-releasing adenosine-triphosphatase (3). Fluoride containing restorative materials are preferred in pediatric dentistry because of their anticariogenic properties. However, fluoride-release and recharge amounts also vary due to the different contents of restorative materials. The aim of this in vitro study was to investigate the fluoride-releasing/recharging and antimicrobial effects of current restorative materials used in pediatric dentistry in distilled water (DW) and artificial saliva (AS).

\section{MATERIAL AND METHOD}

The Ethical Committee of the Marmara University Health Sciences Institute approved the present study under report number 27.02.2014/3.

\section{Dental materials tested in this study}

High-viscosity and resin-modified glass ionomer cement, glass carbomer, compomer, giomer and composite (as control) were tested (Table 1).

Table 1. Chemical compositions of tested materials

\begin{tabular}{|c|c|c|c|}
\hline Material & Species & Chemical composition & Manufacturer \\
\hline $\begin{array}{l}\text { Fuji IX GP } \\
\text { Capsule }\end{array}$ & $\begin{array}{l}\text { High viscosity glass } \\
\text { ionomer cement }\end{array}$ & $\begin{array}{l}\text { Powder: Fluoroaluminosilicate glass, polyacrylic acid dust } \\
\text { Liquid: Polyacrylic acid, polybasic carboxylic acid, distilled water }\end{array}$ & GC, Japan \\
\hline $\begin{array}{l}\text { Fuji II LC } \\
\text { Capsule }\end{array}$ & $\begin{array}{l}\text { Resin modified } \\
\text { glass ionomer } \\
\text { cement }\end{array}$ & $\begin{array}{l}\text { Fluoroaluminosilicate glass, polyalkenoic acid, HEMA, aluminum } \\
\text { chloride, camphorquinone and water }\end{array}$ & GC, Japan \\
\hline GCP Glass Fill & Glass Carbomer & Fluorosilicate glass, apatite, polyacid & GCP, Netherlands \\
\hline Dyract XP & Compomer & $\begin{array}{l}\text { Sr-AI-N-Fluoroaluminosilicate glass, strontium fluoride, } \\
\text { UDMA, TEGDMA, TMPTMA, TCB resin, dimethacrylate resins, } \\
\text { dimethylamino benzoic acid ethyl ester, camphorquinone, BHT, UV } \\
\text { stabilizer }\end{array}$ & Dentsply, Germany \\
\hline Beautifil II & Giomer & $\begin{array}{l}\text { Bis-GMA, TEGDMA, } \\
\text { S-PRG filler, aluminofluoroborosilicate glass, DL-camphorquinone }\end{array}$ & Shofu, Japan \\
\hline Filtek Z 250 & Resin Composite & $\begin{array}{l}\text { Bis-GMA, UDMA, Bis-EMA, zirconia / silica restorative filler, } \\
\text { inorganic filler (60\%) }\end{array}$ & 3M ESPE, Germany \\
\hline $\begin{array}{l}\text { HEMA:2-hydroxyet } \\
\text { resin: Butan 1,2,3,4 } \\
\text { dimethacrylate dim }\end{array}$ & $\begin{array}{l}\text { nyl acrylate UDMA: Uretha } \\
\text { tetracarboxylic acid 2-hyc } \\
\text { ethacrylate }\end{array}$ & $\begin{array}{l}\text { dimethacrylate TEGDMA: Triethylene glycol dimethacrylate TMPTMA: Trimethylolpropa } \\
\text { oxymethacrylate BHT: Butylated hydroxytoluene Bis-GMA: Bisphenol A-Glycidyl Methacr }\end{array}$ & $\begin{array}{l}\text { ane trimethacrylate TCB } \\
\text { rylate Bis-EMA: Bisfenol-A }\end{array}$ \\
\hline
\end{tabular}




\section{Preparation of specimens}

Sixty specimens of each material were prepared and placed into cylindrical teflon moulds (5.0 mm diameter $\times 2.0 \mathrm{~mm}$ height). Materials were cured or set according to the manufacturers' instructions. After disc specimens were removed from their moulds, they were stored for 24 hours in a humidor at $37^{\circ} \mathrm{C}$.

\section{Determination of fluoride ion release}

Artificial saliva was prepared similar to other release studies, in order to evaluate the fluoride release of the samples in our study (9). Thirty disc samples were placed in $2 \mathrm{~mL} \mathrm{AS} \mathrm{(} \mathrm{pH}=7.0)$ and the other thirty were placed in $2 \mathrm{~mL} \mathrm{DW}(\mathrm{pH}=5.0)$. Two disc specimens were placed in each plastic test tube. Solutions were replaced at two hours, one, two and seven days, then weekly for seven weeks. At the same time, the amount of released fluoride ions was measured. At each measuring time, each specimen was rinsed with DW, dried and transferred to the plastic test tube with fresh DW/AS. During the entire experiment, all specimens were incubated at a constant temperature of $37^{\circ} \mathrm{C}$ to mimic the oral environment.

One $\mathrm{mL}$ of solution was mixed with $0.1 \mathrm{~mL}$ of TISAB III (total ionic strength adjustment buffer) and the fluoride concentration was measured with a specific fluoride ion electrode (Orion9690BN electrode, Orion Research, Inc., Beverly, USA). Before each session, the electrode was calibrated. The measured fluoride ion concentrations were recorded in ppm.

\section{Fluoride ion recharge with acidulated phosphate fluoride (APF) gel or fluoride varnish}

Following the eight weeks period, the samples were divided into three groups $(n=5)$. Then $5 \mathrm{~mL}$ of $12300 \mathrm{ppm}$ fluoride containing APF gel (Gelato APF Fluoride Gel, Keystone Industries, New Jersey, USA) was applied to the first group for four minutes at room temperature and $0.4 \mathrm{~mL}$ of 22600 ppm fluoride containing fluoride varnish (Duraphat, Colgate-Palmolive Company, China) was applied to the second group. The last group was accepted as the control group. After the samples were removed from the tubes, they were washed and placed again in the newly prepared $2 \mathrm{~mL}$ DW/ AS, without any application to them. In the first and second group, specimens were washed after recharge, placed in plastic tubes with fresh $2 \mathrm{~mL} \mathrm{AS} / \mathrm{DW}$ and stored at $37^{\circ} \mathrm{C}$. The solutions were replaced at the same intervals as before, and the recharged specimens also were assessed at these same intervals for the amounts of fluoride-released over another eight weeks.

\section{Evaluation of antimicrobial effects}

The antimicrobial effects of materials against Streptococcus mutans (S. mutans)(ATCC 25175) and Lactobacillus acidophilus (L. acidophilus)(ATCC 11975) were evaluated with an agar diffusion test. Bacterial strains used in the study of antimicrobial activity were obtained from the Refik Saydam Hıfzıssıhha Institute Culture Collection Center, Ankara, Turkey. The strains stored at $-20^{\circ} \mathrm{C}$ were cultured on Mitis Salivarius agar (for S. mutans) and Rogosa SL Agar plates(for L. acidophilus) at $37^{\circ} \mathrm{C}$ for 24 hours in $5 \% \mathrm{CO}_{2}$. Appropriate single colonies from plates were transferred into Hewitt THB Broth (for S. mutans) and Brain-Heart Infusion broth (for L. acidophilus) (10). Suspension of the strains prepared in PBS was then adjusted to 0.5 McFarland scale=approximately $1.5 \times 10^{8}$ bacterial cells in $\mathrm{mL}$. The suspension of S. mutans was inoculated onto the surface of Mitis Salivarius agar and L.acidophilis onto Rogosa SL Agar plates.

To evaluate the antimicrobial effects of the materials, forty disc-shaped specimens $(5.0 \mathrm{~mm} \times 2.0 \mathrm{~mm})$ were prepared from each material. Half of the specimens were used to observe the effect on S. mutans and the other half the effect on L. acidophilus. The specimens prepared for each bacterium were divided into four groups $(n=5)$ to evaluate them at different times (direct, second hour, seventh day, second month) and placed in plastic tubes containing $2 \mathrm{~mL}$ of DW and incubated at $37^{\circ} \mathrm{C}$. For the agar diffusion test, the prepared disk-shaped specimens were placed on petri dishes $(150 \mathrm{~mm}$ in diameter) with a distance of $2.5 \mathrm{~cm}$ between them and $1.5 \mathrm{~cm}$ away from the plate edge. Each petri dish was filled with one sample from each material.

The literature states that the $\mathrm{pH}$ changes of the materials during the setting may be responsible for their antimicrobial effects $(11,12)$. For this reason, agar diffusion tests were repeated for two conditions. Firstly, the materials were set outside and then placed on the agar. Secondly, the materials were set in the agar. Seven wells were opened on the plates for this experiment. Restorative materials were placed in six of these wells so they did not float to the edge of the well. A commercially available toothpaste containing 1450 ppm fluoride was placed in the seventh well to be a positive control.

Plates were then incubated at $37^{\circ} \mathrm{C}$ for 48 hours in $5 \% \mathrm{CO}_{2}$. The presence of the inhibition zones around the specimens were measured. The tests were run in two rounds, five parallel runs and the results were expressed as the diameter of the inhibition area and the findings were evaluated.

\section{Statistical Analysis}

Data were statistically analyzed using the IBM SPSS Statistics 22 (IBM SPSS, Turkey) program. According to Shapiro-Wilk test it was determined that the normal distribution of the parameters was not appropriate. The Mann-Whitney U test was used to compare the two groups of parameters. The Kruskal-Wallis test was used for inter-group comparisons, and the Mann-Whitney $U$ test was used for post-hoc evaluations. The intra-group comparison of the parameters was performed using the Friedman test. Significance was assessed at $p<0.05$.

\section{RESULTS}

\section{Fluoride ion release}

The mean fluoride ion release from each material in both media over eight weeks before fluoride-recharge is shown in Figure 1 and Figure 2. 


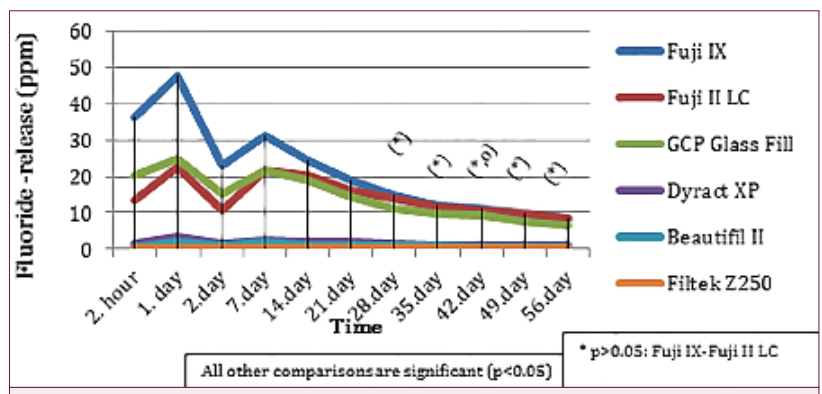

Figure 1. Fluoride-release rates of all materials according to time in distilled water.

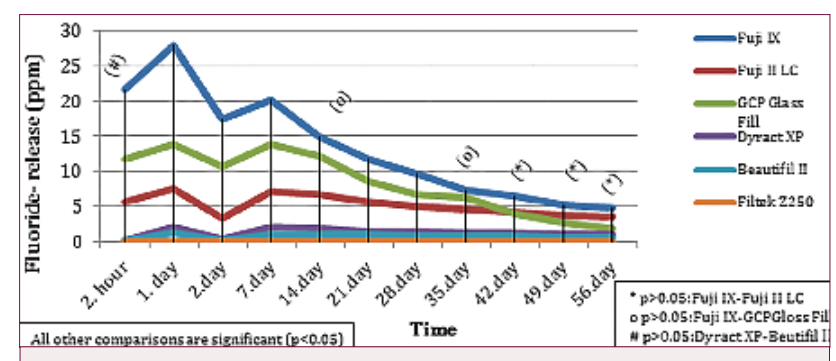

Figure 2. Fluoride-release rates of all materials according to time in artificial saliva

All materials, except for composite, show the highest fluoride-release rates on the first day, which then fell quickly on the second day. On the seventh day, the release rates increased again, and then the amount of fluoride continued to decline on other measurement days, and the decline between successive measurement days was statistically significant $(p<0.05)$.
When the materials in DW are sorted according to the fluoride-release, from highest to lowest at the second hour, the first and second day, the sequence is high-viscosity GIC (Fuji IX), Glass carbomer (GCP Glass Fill), RMGIC (Fuji II LC), compomer (Dyract XP), giomer (Beautifil II) and composite (Filtek Z250). The sequencing was observed as high-viscosity GIC, RMGIC, glass carbomer, compomer, giomer and composite, respectively, in the other measurements (Figure 1). When the amount of fluoride was measured in the AS, high-viscosity GIC released the highest fluoride until the forty-second day, followed by glass carbomer, RMGIC, giomer, compomer and composite, respectively. On the other days, RMGIC released more fluoride than glass carbomer (Figure 2).

Fluoride-release rates of all materials in the DW group were always higher than those in the AS group $(p<0.05)$ (Figure 3 ).

\section{Fluoride-recharge}

Following fluoride-recharge with APF gel and fluoride varnish, there was a burst of fluoride ion release from all materials, except for composite. After recharge, all materials showed the highest release amount at the second hour, and then fluoride amounts declined rapidly in the subsequent measurements. There was a statistically significant difference between the recharge materials for all tested materials in both the DW and the AS at the post-recharge measurement times $(p<0.05)$. Fluoride varnish groups of all materials showed more recharge ability than APF gel groups. No increase in the fluoride-release amounts in the control group was observed. As in the pre-recharge results, all materials showed significantly higher ion release in DW than in AS $(p<0.05)$.

In the DW, the fluoride-release of the materials in the control group was decreased in the sequence of high-viscosity GIC,

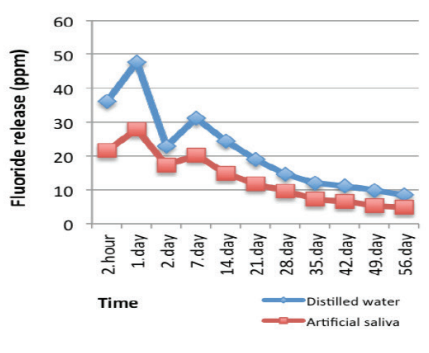

Fuji IX GP

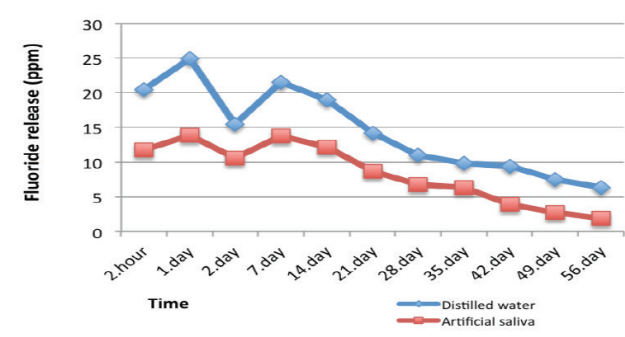

GCP Glass Fill

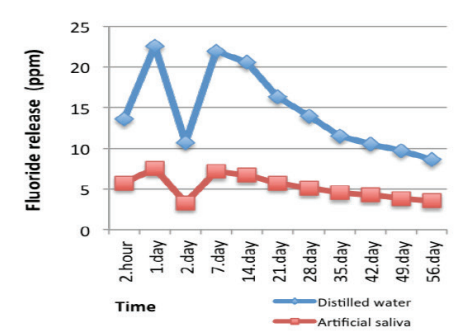

Fuji II LC

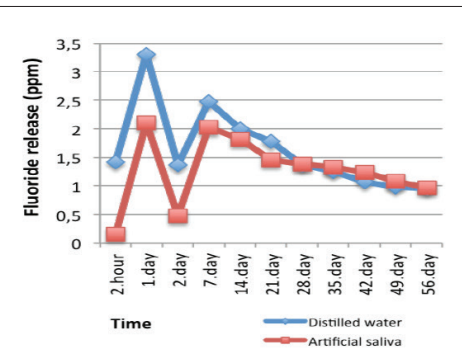

Dyract $X P$

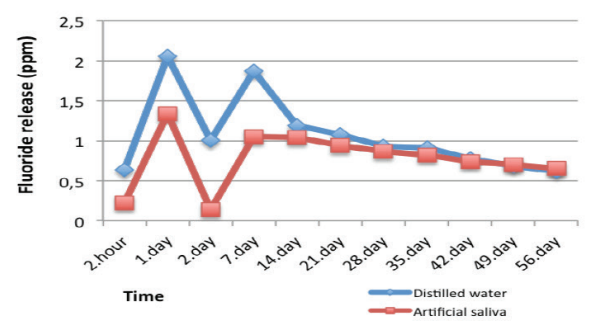

Beautifil II

Figure 3. Fluoride-release of tested material in distilled water and in artificial saliva. 
RMGIC, glass carbomer, compomer, giomer and composite, respectively. In the APF gel group, there was a statistically significant difference in release amounts at all measurement times after recharge $(p<0.01)$. The sequence of the materials from highest to lowest was seen as RMGIC = high-viscosity GIC (no significant difference between two materials $p>0.05$ ), glass carbomer, compomer, giomer and composite. The sequence of the materials in the varnish group was similar to that of the APF gel group. Fluoride-release at the second hour of the materials was reduced in the sequence of high-viscosity GIC, glass carbomer, RMGIC, compomer, giomer and composite, respectively. On and after the thirty-fifth day, RMGIC showed the highest fluoride-release. Similar results were observed in the AS groups (Figure 4, Figure 5).

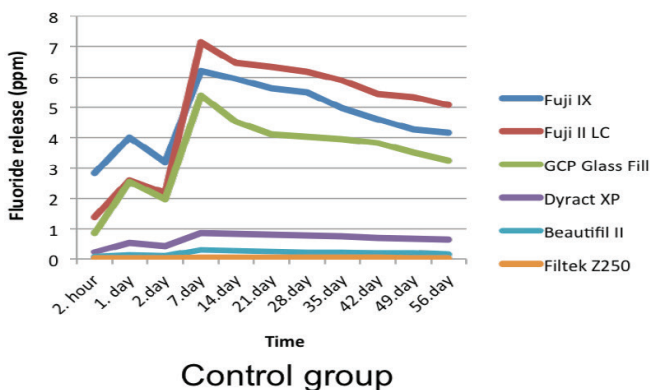

Control group

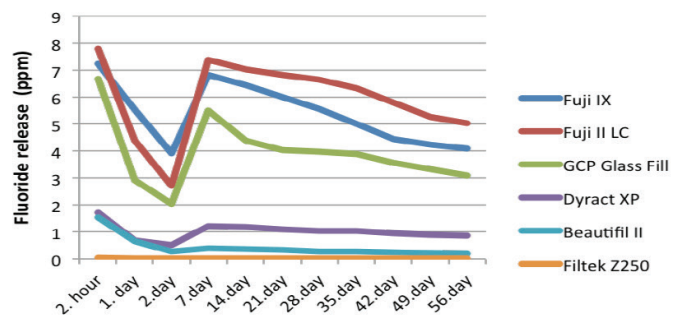

Time

APF gel group

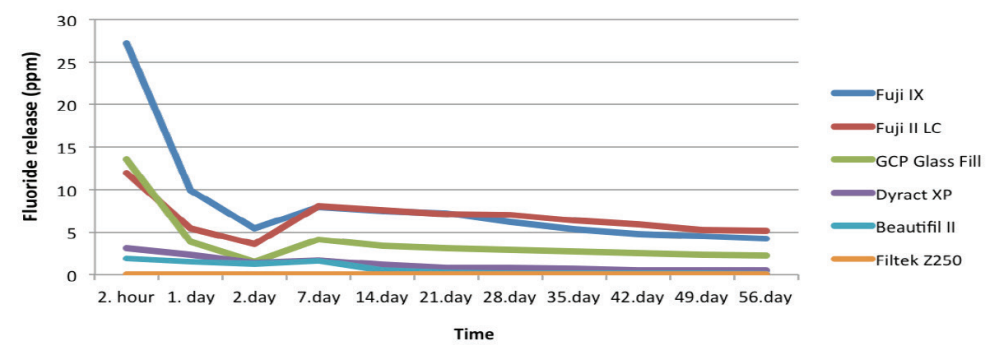

Fluoride varnish group

Figure 4. Fluoride-release from materials in distilled water after recharge.

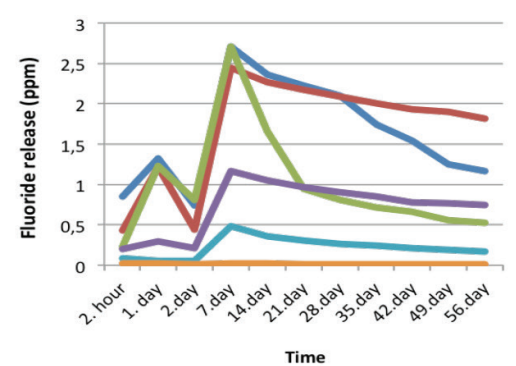

Control group

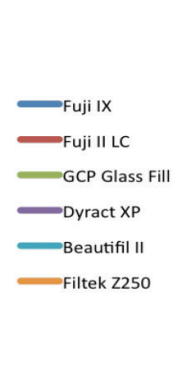

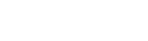

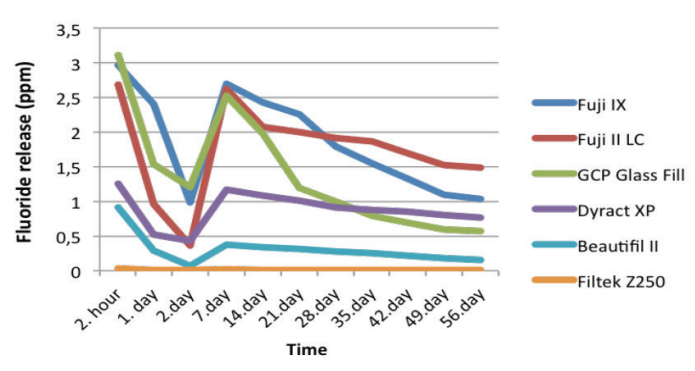

APF gel group

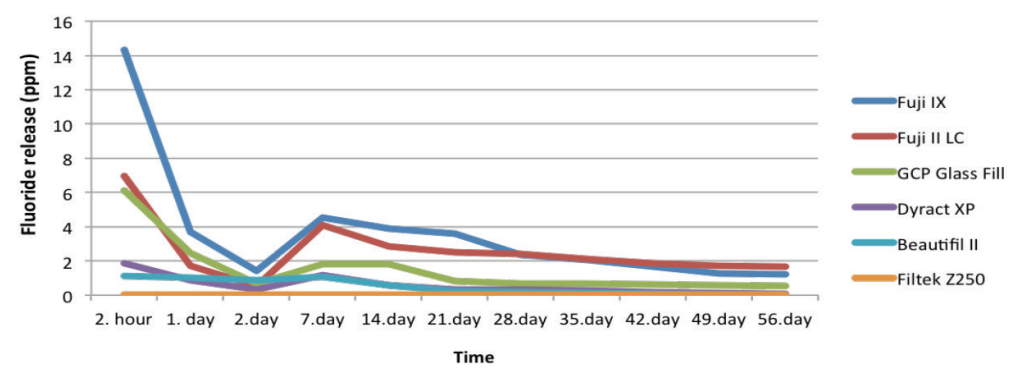

Fluoride varnish group

Figure 5. Fluoride-release from materials in artificial saliva after recharge. 
Post-recharge fluoride-release amounts of all materials, except composite in APF gel and varnish groups, were significantly higher than pre-recharge amounts in both DW and AS ( $p<0.05)$. Release rates of the materials showed an increase at the second hour after recharge with APF gel and varnish, but did not reach the highest release rates before recharge.

\section{Antimicrobial effect}

As a result of the agar diffusion tests performed on the days of the experiment, none of the set materials showed inhibition zone (Figure 6).

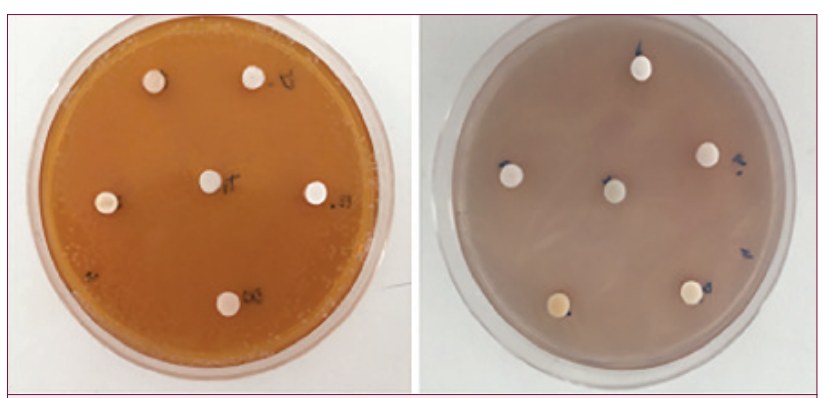

Figure 6. Set specimens placed on both Rogosa SL and MS agar

When the samples were set after placing in the agar, only RMGIC showed an inhibition zone ( $3 \mathrm{~mm}$ ) on S. mutans (Figure 7). No inhibition zone was observed on L. acidophilus (Figure 8). A large inhibition zone around the toothpaste was observed on both media.

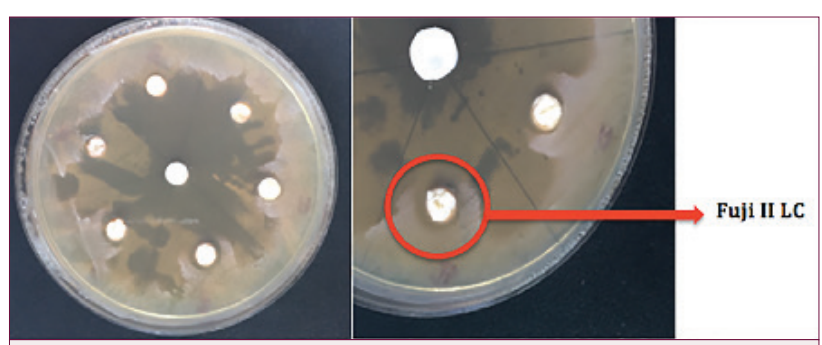

Figure 7. Inhibition zone on S. mutans

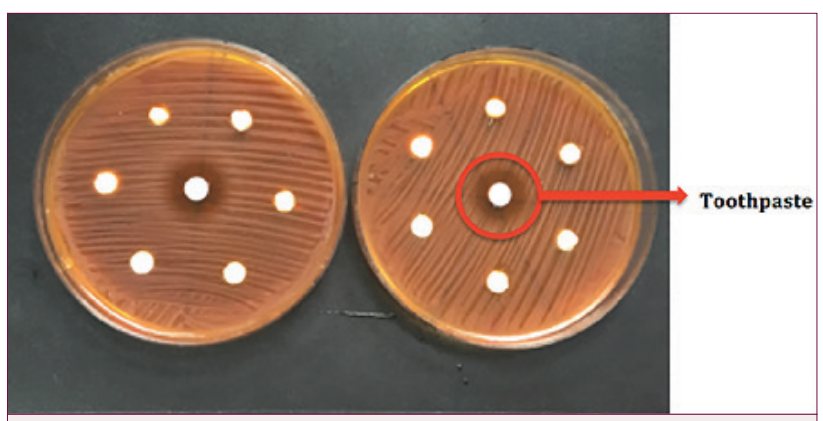

Figure 8. Inhibition zone on L. acidophilus

\section{DISCUSSION}

\section{Fluoride ion release}

The anticariogenic effects of fluoride-releasing materials are proportional to the amount of released fluoride. Studies on glass ionomer cements have found that there are two processes during fluoride-release: a rapid release occurs in the first of these, followed by a slower release through diffusion in the long term $(3,13)$.

In the present study, fluoride-release from tested materials in DW and AS was compared. The highest release was found in high viscosity GIC, followed by glass carbomer, RMGIC, compomer and giomer, respectively. Similar to our study Mousavinasab and Meyers (14) compared the amounts of fluoride-release from high-viscosity GIC, RMGIC, compomer and giomer in DW. Scientists found that the highest release was in high-viscosity GIC, followed by RMGIC and lowest in the giomer. Meanwhile, Hasan et. al. (15) stated in their study that glass carbomer showed the highest fluoride-release, followed by high-viscosity GIC and RMGIC respectively. According to these results we believe fluoride ions in RMGIC have a lower fluoride release because the resin matrix surrounds them $(2,14)$. We also found that the fluoride amount order of materials in the AS was the same as the materials in the DW. It has been determined that the environment in which the materials are stored does not change the sequence of the materials, but affects fluoride-release quantities. For this reason, it is thought that the contents of the materials play an important role in the ion release.

Giomer, used in the present study, showed the lowest release rate in both media. This finding of our study is similar to the findings of Jingawar et al. (16) and Abdul-Quader et al. (4). Lower fluoride-release from the giomer is explained by the presence of S-PRG fillers as a fluoride component. Because the glass particles in the giomer do not undergo a pronounced acid-base reaction, they contain very little glass ionomer matrix phase $(14,16)$.

According to our study, measured fluoride amount from glass carbomer was found to be close to RMGIC in both media, lower than high viscosity GIC and higher than other materials. Similarly, Kucukyilmaz et. al. (17) reported in their study that the highest release in the high-viscosity GIC was followed by glass carbomer. In their study of glass carbomer, Thanjal et al. (18) stated that the release of fluoride is reduced when heat is applied according to the manufacturer's recommendation.

Many studies on short- and long-term fluoride-release of glass ionomer cements have shown that the highest release rate was recorded on day one, then declines rapidly, until it reaches a stable level $(19,20)$. All the materials in the study showed the highest fluoride-release on day one, and fluoride continued to be released in relatively low amounts until day fifty-six. Glass ionomer cements and glass carbomer showed a much higher fluoride amount on the first day than other materials. Comparable to our findings, Basso et al. (20) stated that all glass ionomer 
cements in their study showed the highest release values on day one and continued to decrease in release until day 28 . The high release rate in the first day from the glass ionomer-based materials was probably due to the initial burst effect of the fluoride-containing glass particles (2).

All ions, including fluoride, are released in greater amounts in acid than in neutral conditions. This is associated with increased rates of overall degradation of the glass-ionomer as indicated by increases in roughness on storage in acid $(3,13)$. Yusoff et al. (21) compared fluoride-release from CGIC, RMGIC and compomer in DW and AS. All materials released more fluoride in water than AS. In accordance with these studies, in the present study, fluoride-release from all materials in $\mathrm{AS}(\mathrm{pH}=7,0)$ showed significantly lower release rate than $\mathrm{DW}(\mathrm{pH}=5,0)$ at all measurement times $(p<0.05)$.

\section{Fluoride ion release after recharge}

Studies in the literature have shown that fluoride released from dental materials decreases over time. Therefore these materials need to be recharged with fluoride agents at certain intervals to continue the anticariogenic effects and fluoride-release in the oral environment. As fluoride-release varies according to the materials, post-recharge release is dependent on the type of material and the kind of applied agent $(3,15,22)$.

Abdul-Quader et al. (4) compared the fluoride-release/recharge properties of high-viscosity GIC, compomer and giomer. All materials exhibited the ability to recharge with fluoride, and the highest release rate before and after recharge was seen in high-viscosity GIC. Likewise in our study release rate of materials after recharge was similar to pre-recharge sequence. The highest release after recharge was again observed in the high-viscosity glass ionomer cement, while the lowest was found in the giomer. Glass carbomer showed higher release amount than RMGIC in the control and APF groups in the AS. At other measurement times, RMGIC showed a higher release amount than glass carbomer in all groups $(p<0.05)$. Lopes et. al. (23) compared fluoride-release/recharge pattern of high-viscosity GIC, RMGIC, glass carbomer and compomer. In accordance with our results, high-viscosity GIC in their study showed the highest fluoride release. The released fluoride amounts from RMGIC and glass carbomer were close to each other before and after recharge.

All of the materials used in the present study showed more fluoride-release in DW $(\mathrm{pH}=5.0)$ than in $\mathrm{AS}(\mathrm{pH}=7.0)$ at all measurement times. Naoum et al. (24) evaluated fluoride-release and recharge properties of four dental materials in DW and lactic acid. The release of all materials in lactic acid was found to be higher than in the distilled water groups. The difference between AS and DW is explained by the fact that increasing the porosity of the materials in the acidic environment also increases the release of ions.

We found that release rate of all materials increased after recharge with APF gel and fluoride varnish. The highest increase was seen in the fluoride varnish group, which has the high flu- oride concentration. Likewise, Fallahinejad-Ghajari et al. (25) evaluated fluoride-release of three GIC recharged with $\mathrm{NaF}$ and APF gels. Measured fluoride amount from all materials increased after recharge, but the highest increase was observed in the APF gel group, the group with the high concentration of fluoride.

Bansal and Bansal (26) examined the fluoride-release and recharge ability of restorative materials. They stated that all materials showed a high level of fluoride in the first measurement, but then they showed a sharp decrease. In accordance with these investigators, in our study, all materials showed the highest fluoride-release in the second hour after recharge. On the first day measurement, a sudden drop was detected, and this decline continued to pre-recharge fluoride values within one week. The high fluoride amount measured in the first 24 hours after application of fluoride agents is explained by washout of fluoride ions that are retained on the surface or in the pores of the restorative material $(3,7)$.

In the present study, the fluoride-release values of the materials recharged with APF gel and fluoride varnish increased, but none reached the fluoride values of day one. Materials can't reach the initial fluoride amount after fluoride recharge, because of the wearing down of the materials (27).

\section{Antimicrobial effect}

Fluoride-release quantities in various materials show the antimicrobial capacity of the material. Some researchers report that the low $\mathrm{pH}$ value during the setting reactions of glass ionomer cements is more effective on antimicrobial effect than the fluoride-release and that they do not show any antimicrobial activity after setting has been completed $(12,28)$.

In the present study none of the groups showed any inhibition zones in the agar diffusion tests with set specimens. In accordance with our study, Vermeersch et al. (11) investigated the antimicrobial effects of GIC, RMGIC and composite on S. mutans by agar diffusion test and compared the effects of set and unset materials. While none of the set specimens showed antimicrobial effect, only GIC and RMGIC showed antimicrobial effect from unset specimens. They suggested there was a significant relationship between the acidity of the material and the inhibition zone.

Vermeersh et al. (11) stated that the samples set in the agar exhibited antimicrobial effect. In their study comparing the antibacterial activities of high-viscosity GIC, RMGIC and compomer, Tiwari et. al. (29) reported that there was no inhibition zone in the compomer, while an inhibition zone occurred in other materials. They thought that this result might be related with dissimilarity in release of fluoride and setting mechanisms. However in our study, only RMGIC formed an inhibition zone around the materials that were set in the agar. We thought that the reason for this result is caused by the difference in setting reactions. The RMGIC has two-stage setting reaction, the first is the acid-base reaction, and the second is the light activation. This mechanism may increase fluoride release and antimicro- 
bial effect during setting reaction. In accordance with the present study, Yeşilyurt et al. (12) separated the GIC specimens into two groups, set and unset specimens. After the materials are set, they didn't form an inhibition zone, while a small inhibition zone is formed in unset specimens. Fluoride released from the materials is thought to be insufficient to generate the inhibition zone.

Studies indicate the amount of fluoride required to prevent caries has not yet been determined. The use of long-term fluoride-releasing dental materials should be preferred, especially in patients with moderate to high risk of caries, until the ideal fluoride concentration is determined $(2,30)$.

\section{CONCLUSION}

In conclusion our results proved that the fluoride release and recharge capacity of resin-based materials is less than glass ionomer-based materials. The release rate of the materials is reduced in AS and glass carbomer can be used as an alternative to glass ionomer cements in terms of fluoride-release. It was found that the fluoride amount released from the materials was inadequate to prevent bacterial growth. It is important to know the physical and mechanical properties of restorative materials used in pediatric dentistry as well as the fluoride-release and recharge properties of these materials in clinical material choice.

Ethics Committee Approval: The Ethical Committee of the Marmara University Health Sciences Institute approved the present study under report number 27.02.2014/3.

Peer-review: Externally peer-reviewed.

Author Contributions: Concept - B.S.Ç., S.A., A.Y.; Data Collection and/ or Processing - B.S.Ç., B.A., B.T.A.; Analysis and/or Interpretation - B.S.Ç., B.A., B.T.A.; S.A., A.Y., T.K.; Literature Search - B.S.Ç., B.A., B.T.A.; S.A., A.Y., T.K.; Writing - B.S.Ç.; Critical Reviews - B.S.Ç., S.A., A.Y.

Conflict of Interest: The authors have no conflict of interest to declare.

Financial Disclosure: This study was supported by Marmara University Scientific Research Commission Presidency, project number SAG-CDRP-100914-0314. The funders had no role in study design, data collection and analysis, decision to publish, or preparation of the manuscript.

Etik Komite Onayı: Marmara Üniversitesi Sağlık Bilimleri Enstitüsü Etik Kurulu bu çalışmayı 27.02.2014/3 rapor numarasıyla onaylamıştır.

Hakem Değerlendirmesi: Dış bağımsız.

Yazar Katkıları: Fikir - B.S.Ç., S.A., A.Y.; Veri Toplanması ve/veya İşlemesi - B.S.Ç., B.A., B.T.A.; Analiz ve/veya Yorum - B.S.Ç., B.A., B.T.A.; S.A., A.Y., T.K.; Literatür Taraması - B.S.Ç., B.A., B.T.A.; S.A., A.Y., T.K.; Yazan - B.S.Ç.; Eleştirel İnceleme - B.S.Ç., S.A., A.Y.

Çıkar Çatışması: Yazarlar cıkar catışması bildirmemişlerdir.
Finansal Destek: Bu çalışma Marmara Üniversitesi Bilimsel Araştırma Komisyonu Başkanlığı tarafından SAG-C-DRP-100914-0314 proje numarası ile desteklenmiştir. Fon sağlayıııların çalışma tasarımı, veri toplama ve analizi, yayınlama kararı veya makalenin hazırlanmasında rolü olmamıştır.

\section{REFERENCES}

1. Khoroushi M, Keshani F. A review of glass-ionomers: From conventional glass-ionomer to bioactive glass-ionomer. Dent Res J (Isfahan) 2013; 10(4): 411-0.

2. Dionysopoulos D, Koliniotou-Koumpia E, Helvatzoglou-Antoniades $\mathrm{M}$, Kotsanos N. Fluoriderelease and recharge abilities of contemporary fluoride-containing restorative materials and dental adhesives. Dent Mater J 2013; 32(2): 296-304. [CrossRef]

3. Wiegand A, Buchalla W, Attin T. Review on fluoride-releasing restorative materials - fluoride release and uptake characteristics, antibacterial activity and influence on caries formation. Dent Mater 2007; 23(3): 343-62. [CrossRef]

4. Abdul Quader SM, Shamsul Alam M, Bashar AKM, Gafur A, A Mansur MA. Compressive Strength, Fluoride Release and Recharge of Giomer. Updat Dent Coll J 2012; 2(2): 28-37. [CrossRef]

5. Koenraads H, Van der Kroon G, Frencken JE. Compressive strength of two newly developed glass-ionomer materials for use with the Atraumatic Restorative Treatment (ART) approach in class II cavities. Dent Mater 2009; 25: 551-6. [CrossRef]

6. Zainuddin N, Karpukhina N, Law RV, Hill RG. Characterisation of a remineralising Glass Carbomer ${ }^{\circledast}$ ionomer cement by MAS-NMR Spectroscopy. Dent Mater 2012; 28: 1051-8. [CrossRef]

7. Mungara J, Philip J, Joseph E, Rajendran S, Elangovan A, Selvaraju G. Comparative evaluation of fluoride release and recharge of pre-reacted glass ionomer composite and nano-ionomeric glass ionomer with daily fluoride exposure: An in vitro study. J Indian Soc Pedod Prev Dent 2013; 31(4): 234-9. [CrossRef]

8. Nicholson JW, Czarnecka B. The release of ions by compomers under neutral and acidic conditions. J Oral Rehabil 2004; 31(7): 665-70. [CrossRef]

9. Sato $\mathrm{Y}$, Sato T, Niwa M, Aoki H. Precipitation of octacalcium phosphates on artificial enamel in artificial saliva. J Mater Sci Mater Med 2006; 17(11): 1173-7. [CrossRef]

10. Hoszek A, Ericson D. In vitro fluoride release and the antibacterial effect of glass ionomers containing chlorhexidine-gluconate. Oper Dent 2008; 33(6): 696-701. [CrossRef]

11. Vermeersch G, Leloup G, Delmee M, Vreven J. Antibacterial activity of glass-ionomer cements, compomers and resin composites: relationship between acidity and material setting phase. J Oral Rehabil 2005; 32: 368-74. [CrossRef]

12. Yesilyurt C, Er K, Tasdemir T, Buruk K, Celik D. Antibacterial activity and physical properties of glass-ionomer cements containing antibiotics. Oper Dent 2009; 34: 18-23. [CrossRef]

13. Moreau JL, Xu HH. Fluoride releasing restorative materials: Effects of $\mathrm{pH}$ on mechanical properties and ion release. Dent Mater 2010; 26(11): 227-35. [CrossRef]

14. Mousavinasab SM, Meyers I. Fluoride release by glass ionomer cements, compomer and giomer. Dent Res J (Isfahan) 2009; 6(2): 75-81.

15. Hasan A, Sidhu S, Nicholson J. Fluoride release and uptake in enhanced bioactivity glass ionomer cement ("glass carbomer ${ }^{\mathrm{TM} "}$ ) compared with conventional and resin-modified glass ionomer cements. J Appl Oral Sci 2019; 27: e20180230. [CrossRef]

16. Jingawar MM, Pathak A, Bajwa NK, Sidhu HS.Quantitative assessment of fluoride release and recharge ability of different restorative materials in different media: An in vitro study. J Cli Diagn Res 2014; 8(12): 31-4. [CrossRef] 
17. Kucukyilmaz E, Savas S, Kavrik F, Yasa B, Botsali MS. Fluoride release/recharging ability and bond strength of glass ionomer cements to sound and caries-affected dentin. Niger Clin Prac 2017; 20(2): 226-34. [CrossRef]

18. Thanjal NK, Billington RW, Shahid S, Luo J, Hill RG, Pearson GJ. Kinetics of fluoride ion release from dental restorative glass ionomer cements: the influence and radiant heat and glass composition. J Mater Sci Mater Med 2010; 21(2): 589-95. [CrossRef]

19. Upadhyay S, Rao A, Shenoy R. Comparison of the amount of fluoride release from nanofilled resin modified glass ionomer, convetional and resin modified glass ionomer cements. J Dent (Tehran) 2013; 10(2): 134-40.

20. Basso GR, Della Bona A, Gobbi DL, Cecchetti D. Fluoride release from restorative materials. Braz Dent J 2011; 22(5): 355-8. [CrossRef]

21. Yusoff NNAbN, Ariffin Z, Hassan A, Alam MK. Fluoride Release from Dental Restorations in De-lonized Water and Artificial Saliva. J Int Med 2013; 20(5): 635-8.

22. Rao BSR., Moosani GKR., Shanmugaraj M., Kannapan B., Shankar BS., Ismail PMS. Fluoride Release and Uptake of Five Dental Restoratives from Mouthwashes and Dentifrices J Int Oral Health 2015; 7(1): 1-5.

23. Lopes CM, Galvan J, Chibinski AC, Wambier DS. Fluoride release and surface roughness of a new glass ionomer cement: glass carbomer. Rev Odontol UNESP 2018; 47(1): 1-6. [CrossRef]

24. Naoum S, Ellakwa A, Martin F, Swain M. Fluoride release, recharge and mechanical property stability of various fluoride-containing resin composites. Oper Dent 2011; 36(4): 422-32. [CrossRef]
25. Fallahinejad-Ghajari M, Torabzadeh $\mathrm{H}$, Safavi N, Sohrabi A, Ardakani FF. Fluoride release from three glass ionomers after exposure to sodium fluoride and acidulated phosphate fluoride gels. Dent Res J (Isfahan) 2014; 11(5): 604-9.

26. Bansal R, Bansal T. A comparative evaluation of the amount of fluoride release and re-release after recharging from aesthetic restorative materials: an in vitro study. J Clin Diagn Res 2015; 9(8): 11-4. [CrossRef]

27. Ahn SJ, Lee SJ, Lee DY, Lim BS. Effects of different fluoride recharging protocols on fluoride ion release from various orthodontic adhesives. J Dent 2011; 39(3): 196-201. [CrossRef]

28. Türkün LS, Türkün $M$, Ertuğrul F, Ates $M$, Brugger $S$. Long-term antibacterial effects and physical properties of a chlorhexidine-containing glass ionomer cement. J Esthet Restor Dent 2008; 20(1): 29-44. [CrossRef]

29. Tiwari S, Kenchappa M, Bhayya D, Gupta S, Saxena S, Satyarth S, Singh A, Gupta M. Antibacterial activity and fluoride release of glass-ionomer cement, compomer and zirconia reinforced glass-ionomer cement. J Clin Diagn Res 2016; 10(4): ZC90-3. [CrossRef]

30. Farrugia C, Camilleri J. Antimicrobial properties of conventional restorative filling materials and advances in antimicrobial properties of composite resins and glass ionomer cements-A literature review. Dent Mater 2015; 31: 89-99. [CrossRef] 